Arab World English Journal (AWEJ) Volume 12. Number2 June 2021

DOI: https://dx.doi.org/10.24093/awej/vol12no2.13

\title{
Involvement in Extracurricular Activities and Overcoming High Levels of Communication Apprehension among Saudi EFL Majors
}

\author{
Lubna Alnaeem \\ Department of English Language and Literature \\ College of Languages and Translation \\ Imam Mohammad Ibn Saud University \\ Riyadh, Saudi Arabia
}

Received: $1 / 13 / 2021$

Accepted: 5/31/2021

Published: 6/24/2021

\section{Abstract}

This study attempted to examine the relationship between participation in extracurricular activities and levels of Communication Apprehension (CA) among English as a foreign language (EFL) students and explore the students' perspectives of how extracurricular activities affect their communication skills. The study addressed the following two questions: a) what is the relationship between EFL students' involvement in extracurricular activities and their level of Communication Apprehension?, b) What are the EFL students' perspectives regarding the effect of extracurricular activities on their communication skills?. The participants were 40 EFL students among 80 who participated in extracurricular activities at the College of Languages and Translation at Imam Mohammed bin Saud Islamic University in Riyadh. The participants were asked to complete a Personal Report of Communication Apprehension (PRCA-24) to examine their levels of CA as well as a questionnaire about their attitudes toward extracurricular activities. Additionally, semi-structured interviews were conducted with 8 participants to explore their perspectives in depth. The findings showed that most participants had moderate levels of CA and that $100 \%$ of the participants agreed that participation in extracurricular activities helped them reduce $\mathrm{CA}$ and improve their communication skills. The study also showed that extracurricular activities were more helpful than classroom activities in improving communication skills. This study is significant in that it shed the light on the importance of involvement in extracurricular activities and their role in improving EFL students' communication skills and lowering CA levels. Thus, it is recommended to encourage EFL students to participate in extracurricular activities and consider including such activities in course requirements and teaching materials.

Keywords: communication apprehension, communication skills, extracurricular activities, Saudi EFL majors

Cite as: Alnaeem, L. (2021). Involvement in Extracurricular Activities and Overcoming High Levels of Communication Apprehension among Saudi EFL Majors. Arab World English Journal, 12 (2) 185-208. DOI: https://dx.doi.org/10.24093/awej/vol12no2.13 


\section{Introduction}

Learning English as a foreign language is not without challenges, as it involves developing a target language without full exposure to it outside the classroom. Researchers have always asserted that communication in the target language helps EFL learners improve their language and leads to educational and academic achievements. Rubin, Graham, and Mignerey (1990) strongly agreed that college success is highly correlated to students' communication skills. However, many EFL learners are restricted to classroom learning environments that do not always offer ample opportunities to communicate and interact via the target language in a way that resembles real-life situations and satisfies basic needs. In such cases, EFL learners usually learn the language within classroom boundaries, particularly in traditional learning classes, where the teacher takes the dominant role and students are mostly passive recipients of information. Chen and Wang (2013) stated that students in traditional teaching classes are restricted to formal settings that reduce students' interaction and create more passive students.

Learning a foreign language in such a traditional learning situation may lead to higher levels of Communication Apprehension (CA) which might constitute a barrier to learning. It has always been argued that most people experience some levels of $\mathrm{CA}$ and that, as claimed by Bragg (2017), "between $30 \%$ and $40 \%$ of individuals are estimated to experience high levels of CA" (p. 2). Nevertheless, it is highly important to create a rich environment of communication for EFL students through which they can improve their communication skills and lower their levels of CA. Extracurricular activities can provide such environments, allowing students to find different ways of interaction to improve their communication skills and overcome high levels of CA. It has also been argued that students can enhance their subject knowledge, professional development skills, and communication skills through extracurricular activities (Malinovska, 2011).

In the College of Languages and Translation at Imam Mohammed bin Saud Islamic University in Riyadh, some students like to participate in various extracurricular activities and perform various tasks. Those students usually believe in the importance of such activities in improving language and communication skills. On the other hand, some students do not see the importance of extracurricular activities, not only viewing extracurricular activities as unimportant, but believing that such activities consume too much time and effort without benefitting the learning process. Therefore, teachers should consider such differences among students and find opportunities for them to improve communication skills and strengthen their capabilities of building good interpersonal skills among their peers. Teachers should also attract students and motivate them to participate by "advertising a range of extracurricular activities" (Makarova \& Reva, 2017, p.44).

Tchibozo (2007) believed that extracurricular activities create a variety of dimensions in college students' experiences and can emphasize the purpose of higher education. This paper is an attempt to examine the relationship between involvement in extracurricular activities and EFL students' CA levels. Additionally, the study intend to explore students' perspectives regarding the effect of participation in extracurricular on their communication skills.

It has been claimed that all individuals experience some level of fear of public and interpersonal speaking, accompanied by feelings of anxiety and nervousness (Bodie, 2010). 
However, such fears may hinder students' progress and constitute an obstacle that prevents students from reaching higher levels of language proficiency. LeFebvre, LeFebvre, and Allen (2018) stated that "Fear and anxiety are potentially critical barriers to students' learning and success" (p.2). This indicates a need to engage students in a variety of tasks that can help them overcome such fears. Participating in extracurricular activities can be a good way to help students overcome their communication fears and reduce high levels of CA. It has been strongly argued that involvement in extracurricular activities is not less important than attending regular classes (Eccles, Barber, Stone, \& Hunt, 2003; Mahoney, Beverley, \&Thomas, 2003).

As an assistant professor at the College of Languages and Translation at Imam Mohammed bin Saud Islamic University in Riyadh, I have observed that many students are not active in class. Those students rarely participate in class discussions and do not like to answer questions or speak in front of their peers. They also try to avoid working in groups or interacting with other students, preferring to work individually. However, those students perform better on written exams compared to their oral performance. This means that the desire not to participate might not be due to a lack of knowledge but to high levels of CA.

Hence, This study was intended to examine the relationship between the involvement of EFL students in extracurricular activities and levels of CA among participants at the College of Languages and Translation at Imam Mohammed bin Saud Islamic University in Riyadh. Moreover, the study was intended to explore students' perspectives of how extracurricular activities affect their communication skills. The researcher intend to help EFL students improve their communication skills and reduce levels of CA in a more enjoyable and beneficial way through participating in extracurricular activities and develop as an EFL teacher and the head of the extracurricular activity unit.

The results of this study can shed the light on the importance of involvement in extracurricular activities and the role that such activities can play in improving EFL students' communication skills and lowering CA levels. Additionally, the study can show how students perceive the effect of extracurricular activities on their communication skills in a way that can make such activities more helpful and effective to accomplish their goals.

The questions of the present study are formulated as follows:

1- What is the relationship between EFL students' involvement in extracurricular activities and their level of CA?

2- What are the EFL students' perspectives regarding the effect of extracurricular activities on their communication skills?

The main objectives of this research are to study the relationship between involvement in extracurricular activities and EFL students' level of CA and examine the students' perspectives regarding the effect of such activities in a way that helps in understanding these effects and considering the contribution that they may offer in the development of EFL students communication skills.

\section{Literature Review}

CA is defined as the level of anxiety or fear that an individual faces during communication, whether anticipated or real, with others (McCroskey, 1982; 1984). Payton and 
Scott (2013) added that CA is "a social anxiety disorder and, in its extreme form, is considered a social phobia"(p.2). CA and the associated feelings of fear and anxiety have been rich areas of investigation throughout the decades, attracting the attention of researchers in various fields (Byrne, Flood,\& Shanahan, 2012; McCroskey, 2009; McCroskey, Teven, Minielli, \& Richmond McCroskey, 2014). The effect of CA on students has been emphasized in research because CA levels are highly associated with students' academic achievements. McCroskey, BoothButterfield, and Payne (1989) argued that "academically, we would expect lower grade point averages and higher dropout rates among high CA students compared to those with low CA" (p. 101). This might be attributed to the fact that higher levels of CA usually elicit anxiety and feelings of stress, discomfort, and unwillingness to participate in communicative situations among students, which in turn "leads to avoidance behaviors, cognitive deficits, and performance failures" (p.101). Students with higher levels of CA will try to avoid any task that requires interaction and communication in academic situations, which usually results in an ineffective way of remembering course content (Freimuth, 1976).

In a qualitative study to explore the phenomenon of CA among students with high levels of CA, Bragg (2017) found that teaching materials do not provide enough opportunities for oral presentation or techniques that help students improve their communication skills. Bragg also found that students with high levels of CA have the same fears and anxiety inside and outside the classroom. CA was also examined in college students from a different angle. Payton and Scott (2013) conducted a study to evaluate whether homeschooled students have higher levels of CA than peers from public and private high schools. To answer this question, they examined levels of CA of college freshmen at four universities in the United States, and the results showed no significance difference between the three groups in their levels of CA.

Foreign or second language teachers should deal with CA carefully as students with higher levels of $\mathrm{CA}$ are expected to be more anxious when communicating in the foreign language and taking on the burden of communication using a language other than their mother tongue (Schlenker\& Leary, 1982). Mahdi (2015) studied the relationship between CA and communicative competence in EFL learners. He found that students face anxiety, stress, and fear that constitute an obstacle to learning and prevent them from interaction. The study also showed that EFL teachers can play a vital role in overcoming these communication difficulties by motivating students to participate in activities. Mahdi suggested some strategies for oral communication and designing EFL curriculum according to the students' background. Mustapha, Ismail, Singh, and Elias (2010) examined CA levels among 50 EFL seniors at the bachelor level in a business administration program, focusing on the types of English language activities that students preferred. The findings showed that the students had moderately high levels of CA and preferred participating in group discussions to help reduce their anxiety.

Involvement in extracurricular activities can allow foreign or second language learners to find a range of opportunities to communicate using the target language (Mahdi, 2015). Extracurricular activities refer to any type of activity that is outside the course curricula. What is interesting about extracurricular activities is that participation is not obligatory, and students do not receive extra academic credit for participation. It is totally voluntary (Makarova \& Reva, 2017). Thus, students who join these activities have the desire to participate and show their talents. Extracurricular activities offer a kind of communication that is more relaxed and flexible, 
without classroom restrictions and the fear of being graded that many students may suffer from. Olibie and Ifeoma (2015) highly recommended that students be provided ample opportunities for meaningful participation in institution-facilitated extracurricular activities within the community.

In recent decades, there has been a noticeable shift in educational practices that placed much attention on extracurricular activities as a source of additional benefits for students (Malinovska, 2011). Montelongo (2002) believes that "A variety of student development changes in regards to cognitive and affective growth are associated with participation in college extracurricular activities" (p. 50). Some researchers believe that extracurricular activities do not need teacher organization or supervision (Eccles et al., 2003). Others argue that extracurricular activities should be performed under careful supervision by teachers and educators in a way that emphasizes communication and leadership skills in addition to positive proficiency developments for the students. (Simoncini \& Caltabiono, 2012).

The effect of extracurricular activities on students' communication skills has received a considerable amount of researchers' attention. Jamal (2012) investigated the effect of participating in extracurricular activities on interpersonal skills and professional behaviors from the perspectives of undergraduate medical students. The study also involved the factors that can help in developing extracurricular activities and facilitating students' participation. The researcher used semi-structured interviews with nine students who participated in extracurricular activities at King Abdulaziz University in Jeddah, KSA. The results showed that the participants gained many communication and interpersonal skills, such as problem solving, teamwork, leadership, and self-reflection skills, which positively influenced their academic achievements.

Tchibozo (2007) examined the effects of extracurricular activities on graduates' communication skills and the transitional process from higher education to the labor market using a survey of 119 graduates in the UK who participated in extracurricular activities at their universities. The results of the study showed that involvement in extracurricular activities had a significant influence on the transition process, and Tchibozo suggested some strategies related to extracurricular activities to support the transition to work. Makarova and Reva (2017) studied the effect of participation in extracurricular activities on foreign language university students in Canada and Russia. The results showed that only about one-third of the students in these two countries had participated in extracurricular activities and that Canadian students usually participated in activities inside their universities, while Russian students participated in activities outside their universities. Most participants believed that participating in extracurricular activities helped them improve their communication and language skills, and they all agreed that trips abroad were the most effective activities.

de Prada Creo, Mareque, and Portela-Pino, (2020) investigated the effect of extracurricular activities on university students' skills of teamwork and found that there was a significant correlation between extracurricular activities and students' acquisition of communication skills and essential team work skills. Saibovich (2019) examined the relationship between extracurricular activities and university students' academic achievements, development of skills, and the role of parents in shaping students interest in such activities. The study showed that there was a positive direct and indirect influence of extracurricular activities on students' academic achievements and the development of flexible communication skills. Nghia, T. L. H. 
(2017). Studied the influence of extracurricular activities on developing generic skills of university students and the contributing factors that affect the development of these skills through extracurricular activities. The study showed that there was a lack of autonomy in university curriculum that could be achieved through extracurricular activities which proved to be successful in developing the students' generic skills.

In spite of the fact that many research has been done to examine the relation between participating in extracurricular activities and students' communication skills, examining the effect of such activities on EFL students' levels of CA and their perspectives is not given enough attention which constitutes a literary gap. This study examined the correlation between participation in extracurricular activities and EFL students' levels of CA. It also represents an exploration of students' perspectives regarding the effects of participation in extracurricular activities on their communication skills.

\section{Methods}

\section{Research Design}

This study involved a mixed-approach design, using both quantitative and qualitative measures to accomplish the research goal. The PRCA-24 developed by McCroskey was used in this study to measure the participants' level of CA. (See Appendix A). Details on the PRCA-24 will be given later. A questionnaire was also used to gain a general overview of the participants' attitudes toward the effect of extracurricular activities on communication skills (See Appendix B). Additionally, semi-structured interviews were conducted to explore the participants' perceptions of how extracurricular activities affect the students' communication skills in depth (See Appendix C). Quantitative statistical analysis was used to examine the correlation between participation in extracurricular activities and the participants' level of CA. Qualitative analysis was used to explore the students' perceptions.

\section{Participants}

The researcher is the head of the extracurricular activity unit at the college, which enabled her to provide accurate information about the unit. At the beginning of each semester, all students at the College of Languages and Translation at Imam Mohammed bin Saud Islamic University in Riyadh are invited to join the unit through the unit's Twitter account and manual registration; however, not all students join. The total number of students at the college is around 2,600 , but only about 80 students participate in extracurricular activities around $(3.07 \%)$ of the total number of students. Most members of the unit are participants from previous semesters and very few new participants.

The sampling technique followed in this study is purposive sampling based on the characteristics of the sample that help in achieving the objectives of the study. Non-probability sampling method was used because not all students in the college were given the opportunity to participate. The sample of this study was 40 students among the 80 who participate in extracurricular activities at the college; hence, the sample comprises $50 \%$ of the population. The participants come from various study levels at the college: 12 students from level eight, 11 from level seven, four from level six, seven from level five, three from level four, two from level three, and one student from level one. The participants worked on different types of extracurricular activities and performed a variety of roles in such activities. 


\section{Research Instrument}

This study was intended to examine the correlation between participation in extracurricular activities and EFL students' CA level as well as the students' perspectives of how such activities affect their communication skills. To achieve these goals, three instruments were used: PRCA-24, a questionnaire, and semi-structured interviews.

\section{PRCA-24}

McCroskey's PRCA-24 consists of 24 items measuring four contexts of communication: group discussion, meetings, interpersonal conversations, and public speaking. For each context, six statements are used to measure CA via three positively-worded statements and three negatively-worded ones to reduce bias. The tool includes a Likert-type five-point scale, and the respondents chose whether they strongly agree, agree, are undecided, disagree, or strongly disagree.

The scoring formula for the PRCA-24 involves adding or subtracting the value of each statement within each group of six statements from a base score of 18. The result of this calculation is the sub-score of CA for each of the four communication contexts. Adding the subscores of all four contexts gives the total CA score, which can range from 24-120. Scores below 51 indicate a low level of CA, and scores above 80 indicate high level of CA. Scores between 51 and 80 indicate a moderate level of CA. This classification is based on means and standard deviations of scores from over 20, 000 students (McCroskey, 1989). Details on calculating scores and results are contained in the data analysis section.

The participants in the present study were first given the PRCA-24 measurement tool, then asked to complete a questionnaire about their participation in extracurricular activities and general attitudes toward the effect of participation in extracurricular activities on communication skills. Semi-structured interviews were conducted with the participants to explore their perceptions of extracurricular activities and how they affect the students' communication skills in depth.

\section{Validity and Reliability of Instruments} Validity and reliability of PRCA-24

The PRCA-24 is the most widely used tool and dominant instrument in researching CA (Payton \&Scott, 2013). It is preferred above all other measurement tools in measuring CA, including its earlier versions (PRCA, PRCA-10, PRCA-20, etc.; Mustapha et al., 2010). It has a high content validity and an alpha reliability of .97 (McCroskey, Beatty, Kearney, \&Plax,1985). The PRCA-24 has been used in various studies on CA (e.g., Francis \&Miller, 2008; Mustapha et al., 2010; McCroskey et al., 1985; McCroskey et al., 1989; Mahdi, 2015; Payton \&Scott, 2013; Amogne \&Yigzaw, 2013; Rashidi, Yamini, \& Shafiei, 2012).

\section{Validity and Reliability of Questionnaire}

To validate the questionnaire, the researcher sent it to two professors and one assistant professor at the same college, and they all agreed that the questions were clear, suitable to the students, and served the purpose of the study. 
To make sure that the questionnaire was reliable, the researcher used it with seven students as a pilot. As a result of this pilot, question four (How many times have you participated in extracurricular activities?) was modified by adding options for the participants to choose from, because some participants provided open answers such as "many", "a lot," or "too much," which does not serve the purpose of the questionnaire. Therefore, the researcher added the following options: "1-2, 3-4, more than 5".

\section{Validity and Reliability of Interview Guiding Questions}

To validate the interview guiding questions, the researcher sent them to two professors and one assistant professor at the same college. They all agreed that the questions were suitable and could help in answering the research questions to accomplish the goal of the study. The assistant professor suggested that one question be deleted, as it was similar to another question and could be used as a follow-up during interviews if needed. One professor suggested modifying the structure of some questions, such as changing wh-questions to yes/no ones and adding tag questions. He also suggested deleting one question that would not be clear to the participants. The other professor suggested adding one question about the difference between classroom activities and extracurricular activities as a guiding question and elaborating on this issue during the interviews. All suggestions were highly appreciated and considered in modifying the interview guiding questions.

To ensure that the interview guiding questions were reliable, the researcher interviewed three students as a pilot. The questions were clear enough for the students and helped to accomplish the research goal. The follow-up questions may have differed according to how the interviewees answered, which was taken into consideration in the interviews.

\section{Research Procedures}

The present study involved extracurricular activities performed under the supervision of teachers. The teachers and the students in the unit have regular face-to-face and online meetings to discuss the activities. The teachers' basic roles are to facilitate the students' roles and provide guidance in addition to handling administration issues, such as obtaining permission to hold activities and preparing necessary supplies. Activities are selected based on the students' and teachers' suggestions and to mark global and national events, important international days, and important social topics in a way that helps the students improve their language and communication skills. Some distinguished activities presented by the unit have included: Orientation Day, the National Day, a Breast Cancer Awareness Raising Campaign, Teacher's Day, What is Professionalism?, an Understanding Personalities Workshop, Breakfast at Nine: Coworker's Day, a Mental Health Problems Awareness Raising Campaign, a Weekly Smile Campaign, Kids' Day, a Walk 30 Minutes Campaign and a Weekly Encouraging Statements Campaign.

Eighty students participated in the college's extracurricular activities as mentioned earlier. All students were invited to participate in the first part of the study, and they were told that their participation would involve answering the PRCA-24 questions and completing the questionnaire. However, only 40 students were willing to participate. After they consented to participating in the study, they were told that their participation was voluntary and that all information received would be kept confidential and used for the purpose of the study only. The 
40 participants answered the PRCA-24 questions, and their responses were calculated by following the scoring formula that McCroskey (1982) developed. Then, the participants completed the questionnaire. The goal of the questionnaire was to determine how many times they had participated in extracurricular activities. The questionnaire was also designed to provide a general overview of their attitudes toward the effect of extracurricular activities on communication skills. The amount of participation in extracurricular activities was then correlated with the participants' scores on the PRCA-24, with the goal of examining the relationship between them. Details regarding the data analysis are given later.

Eight participants from the 40 who completed the first part of the study were then randomly selected to be interviewed. They were told that their voices would be recorded for transcription purposes, all information would be kept confidential and used for the purpose of the study only, and that their recordings would be deleted following the completion of the study. The participants were given the following pseudonyms for the data analysis: "Rana, Mona, Nouf, Nada, Lena, Yara, Rema, and Hana." Afterward, the researcher began the interviews via telephone, which the interviewees preferred because they could talk at any time during the day. This made them more relaxed and free to converse. Borg (2006) stated that interviews are most commonly conducted in face-to-face situations. However, they can also be conducted using the telephone.

The researcher started by welcoming the participants and thanking them for their generous cooperation and the time they devoted to the interviews. After talking about general issues, the researcher began interviews using the prepared interview guiding questions as well as some follow-up ones depending on the interviewees' answers. All interviews went smoothly and were full of rich information that served the purpose of the study. The researcher received some nice messages via Whatsapp from interviewees expressing their interest in the study and praising her style. This had a very positive impact and pushed her to complete the study with greater motivation and enthusiasm. In addition, the researcher asked the participants some follow-up questions via Whatsapp for the clarification of some points and received the answers as voice notes. Afterward, all interviews were transcribed to be coded and analyzed qualitatively using the grounded theory. Dörnyei (2007) strongly claimed that data analysis using the grounded theory should meet two important criteria: "The data analysis follows the specific sequential coding system advocated by the grounded theory and the analysis produces some theory as an outcome of the investigation" (p. 258). The data collected through interviews in this study were coded and categorized. Then, some relationships between these categories were established to derive a theory. Two professors and one assistant professor at the same college were asked to revise the codes and categories of data to ensure appropriate categorization. High consistency was found between the researcher and the two reviewers in the data categorization. Details regarding the data analysis are given later.

\section{Data Analysis}

In this study, a mixed-method approach was used to answer the research questions. The data were collected using the PRCA-24 tool, a questionnaire, and semi-structured interviews. The data collected through the first two instruments were analyzed quantitatively using Statistical Package for Social Science (SPSS) version 20, and the data obtained from the semistructured interviews were analyzed qualitatively using the grounded theory. 


\section{PRCA-24}

The scores of the participants on the PRCA-24 and the relation of such scores to the number of activities in which they participated were analyzed using SPSS version 20. Descriptive statistics including means and standard deviations were used to express variables. The scores of the participants on the PRCA-24 were grouped according to whether they were low $(<51)$, moderate $(51-80)$, or high $(>80)$ following the scoring formula by McCroskey (1989). The amount of participation in extracurricular activities was classified into three groups: ( $1-2,3-4$, and more than five ). For the purpose of comparing the participants' scores on the PRCA-24 with the number of activities, one-way analysis of variance (ANOVA) was used. The post-hoc test was used to compare the scores when the ANOVA was significant. Significance was accepted at $\mathrm{p}<0.05(*)$.

Table 1.Means and standard deviations of PRCA-24 scores

\begin{tabular}{|l|l|l|l|l|l|}
\hline $\begin{array}{l}\text { Score } \\
\text { PRCA-24 }\end{array}$ & N & Mean & SD & F & Sig \\
\hline $1-2$ & 10 & 62.7 & 14.38 & \multirow{2}{*}{4.1} & \multirow{2}{*}{$0.025^{*}$} \\
\hline $3-4$ & 11 & 60.45 & 13.83 & & \\
\hline 5 and more & 19 & 49.94 & 11.49 & & \\
\hline Total & 40 & 56.02 & 13.88 & & \\
\hline
\end{tabular}

The table shows that the mean of the scores on the PRCA-24 for the 1-2 activity group was 62.7 with a standard deviation of 14.38. The mean of the scores on the PRCA-24 for the 3-4 activity group was 60.45 with a standard deviation of 13.83. The mean of the scores on the PRCA-24 for the more - than - five activity group was 49.94 with a standard deviation of 11.49 . The mean of the scores on the PRCA-24 for the total number of participants was 56.02 with a standard deviation of 13.88. A significant difference was found in the mean of the participants' scores on the PRCA-24 according to the number of activities, as the significance was $\mathrm{F}=4.1,0.025^{*}$, which was $<0.05$.

Table 2. Mean difference of scores in the three groups

\begin{tabular}{|c|c|c|c|c|}
\hline $\begin{array}{c}\text { Number } \\
\text { of Activities }\end{array}$ & $\begin{array}{c}\text { Number } \\
\text { of Activities }\end{array}$ & $\begin{array}{c}\text { Mean } \\
\text { Difference }\end{array}$ & Std. Error & Sig. \\
\hline $1-2$ & $3-4$ & 2.24 & 5.63 & 0.916 \\
\hline $1-2$ & 5 and more & $12.75^{*}$ & 5.03 & $0.041^{*}$ \\
\hline $3-4$ & 5 and more & 10.50 & 4.88 & 0.093 \\
\hline
\end{tabular}

The table reveals that the mean difference of the scores of the participants in the 1-2 activity group when compared with the $3-4$ activity group was 2.24 . No significant difference was found between the two groups, as the significance was 0.916 , which was $>0.05$. The table also shows that the mean difference of the scores of the participants in the 1 - 2 activity group when compared with the more than five activity group was 12.75 . A significant difference was found between the two groups, as the significance was 0.041, which was $<0.05$. The table furthermore shows that the mean difference of the scores of the participants in the 3 - 4 activity group when compared with the more than five activity group was 10.50 . No significance difference was found between the two groups, as the significance was 0.093 , which was $>0.05$. This indicated that a difference existed between the students with greater levels of participation in activities when compared with those with less participation. 
Arab World English Journal (AWEJ) Volume 12. Number 2. June 2021

Involvement in Extracurricular Activities and Overcoming High Levels

Alnaeem

Table 3.Percentages of scores on PRCA-24 and number of activities

\begin{tabular}{|c|c|c|c|c|c|}
\hline $\begin{array}{c}\text { Number of } \\
\text { Activities }\end{array}$ & Score PSCA -24 & Low & Medium & High & Total \\
\hline \multirow{2}{*}{$1-2$} & Count & 1 & 7 & 2 & 10 \\
\cline { 2 - 6 } & $\%$ & $10.00 \%$ & $70.00 \%$ & $20.00 \%$ & $100.00 \%$ \\
\hline \multirow{2}{*}{$3-4$} & Count & 1 & 9 & 1 & 11 \\
\cline { 2 - 6 } & $\%$ & $9.10 \%$ & $81.80 \%$ & $9.10 \%$ & $100.00 \%$ \\
\hline \multirow{3}{*}{5 and more } & Count & 7 & 12 & 0 & 19 \\
\cline { 2 - 6 } & $\%$ & $36.80 \%$ & $63.20 \%$ & $0.00 \%$ & $100.00 \%$ \\
\hline \multirow{2}{*}{ Total } & Count & 9 & 28 & 3 & 40 \\
\cline { 2 - 6 } & & $22.50 \%$ & $70.00 \%$ & $7.50 \%$ & $100.00 \%$ \\
\hline
\end{tabular}

The table indicates that 10 participants among the 40 who participated in the study (25\%) participated in $1-2$ activities, 11 participants (27.50\%) participated in $3-4$ activities, and 19 participants $(47.50 \%)$ participated in more than five activities. It also shows that nine participants (22.5\%) had low CA, 28 participants $(70 \%)$ had moderate CA, and three participants $(7.5 \%)$ had high CA. Among those who had low CA, one student (11.10\%) participated in 1- 2 activities, one student (11.10\%) participated in 3 - 4 activities, and seven students (77.80\%) participated in more than five activities. Among those who had moderate CA, seven students (25\%) participated in $1-2$ activities, nine students $(32.10 \%)$ participated in $3-4$ activities, and 12 students $(42.90 \%)$ participated in more than five activities. Among those who had high CA, two students (66.70\%) participated in 1-2 activities, one student $(33.30 \%)$ participated in 3-4 activities and zero students $(0 \%)$ participated in more than five activities. The table also shows that among those who participated in 1 - 2 activities, only one participant (10\%) had low CA, seven participants $(70 \%)$ had moderate CA, and two participants $(20 \%)$ had high CA. Among those who participated in 3-4 activities, only one participant $(9.10 \%)$ had low CA, nine participants (81.80\%) had moderate CA, and only one participant $(9.10 \%)$ had high CA. Among those who participated in more than five activities, seven participants $(36.80 \%)$ had low CA, 12 participants $(63.20 \%)$ had moderate CA, and no participants (0\%) had high CA.

\section{The Questionnaire}

The questionnaire was aimed at providing a general overview of the students' perspectives regarding the effect of extracurricular activities on their communication skills. The data collected though this questionnaire showed that $100 \%$ of the participants want to improve their communication skills. It showed that $51 \%$ of the participants want to improve their public speaking skills, $12 \%$ want to improve their meeting skills, 19\% want to improve their group discussion skills, and $18 \%$ want to improve their interpersonal skills. The study also showed that $100 \%$ of the students agree that participating in extracurricular activities help them to improve their communication skills. 
The analysis of the data collected through the questionnaire also showed that students are willing to perform a variety of roles in extracurricular activities. A total of $37 \%$ of the participants indicated that they like to assume leadership roles. Other roles that students like include presenter $(12.5 \%)$, planner $(7.5 \%)$, organizer $(7.5 \%)$, photographer $(5 \%)$, designer $(2.5 \%)$, and trainer $(5 \%)$. A total of $23 \%$ of the participants indicated that they are willing to take on any role that will help to make an activity more successful, and they always think about the final product regardless of who produces it or how it is produced. For example, one of the participants stated, "Almost every role because what matters is how we do it and with whom." The participants believe in teamwork principles and aim to improve the results of the task. The analysis of the data also showed that $100 \%$ of them agreed that assuming these roles in extracurricular activities helped them to improve their communication skills.

Regarding the types of extracurricular activities in which students are interested, $68 \%$ of the participants stated that they like all types of activities. They strongly claimed that the purpose of the activity is the most important factor in choosing the activity, as they all like to help others in various ways and spread positive energy at the college. For example, one of the participants said, "I like volunteering activities at my college and 1 like helping others." In the same respect, another participant stated, "I like to make others happy." A total of $32 \%$ of the participants prefer the types of activities aimed at raising awareness of important social issue, such as women's status, community service, and children's needs. The analysis of the data also showed that 93\% of the participants try to improve their communication skills outside of the college by using English in various activities beyond their homework. The study further showed that $100 \%$ of the students agreed that they would like to participate in extracurricular activities in the future. The suggestions for future activities that the participants provided were almost similar to the types of activities they prefer.

\section{Semi-structured Interviews}

The researcher manually transcribed the semi-structured interviews and carefully revised them to ensure accurate transcription. The researcher read the transcribed interviews carefully more than once, coded them by underlining and highlighting the important parts, and took notes. Then, the following categories were created based on such codes: "communication apprehension, communication skills, classroom activities versus extracurricular activities, and a willingness to participate in the future."

\section{Communication Apprehension}

All eight interviewees agreed that they face some levels of fear or anxiety during communication in English, which is associated with certain factors. For example, Rana believes that for her, the problem arises in the presence of a new person, which can affect her for a few seconds; then, this fear gradually disappears. Mona argued that her source of fear in communication is the incorrect pronunciation of new English words which puts her under stress. Lena sometimes forgets some words and has to stop to remember them, which affects her negatively. However, she asserted, "The problem is not in my personality. I stop to remember the word!". Nada said that she is afraid of other people misunderstanding her during communication, which is a source of anxiety for her. Yara finds herself to be more active and enthusiastic in indirect speech via electronic devices rather than face-to-face communication. This might be, as 
she claimed, "because of eye contact." However, this does not mean that she completely avoids face-to-face communication.

On the other hand, all eight interviewees love to participate in discussions and meetings in English, and they find it easy to express themselves and to understand others. Nouf and Rema agreed that they have strong persuasion skills and can communicate flexibly with others on various occasions. Rema also added that she understands people and persuades them according to their personalities. Mona stated that she loves to speak in front of a large audience, as this gives her more power. She loves to see many people around her and rarely focuses on a few people. She believes that "maybe this is different from my friends. But, it can be a point of strength in my personality." Nada stated that she has high self-confidence and loves to join meetings and express her opinions. She always smiles and gives positive reactions to others. Lena, Yara, and Rana stated that they like to communicate with everyone, everywhere, and about everything. Yara added that she quickly picks up new words and structures from new people, and this boosts her self-esteem in communication. The participants agreed that they overcome CA and improve their communication skills by participating in extracurricular activities, which is discussed below.

\section{Communication Skills}

All of the participants generally agreed on the importance of improving their communication skills as this helps them improve their proficiency levels as EFL learners. Hana stated, "I am not professional. I need to improve myself." They have an inner desire and a great ambition to reach higher proficiency levels through on- going developmental processes. Lena stated, "I want to be professional. I feel that I need to develop, even if I reach high levels, I need to develop." The participants all strongly agreed that they need to make more of an effort to improve their public speaking skills. Mona believes that she needs to improve her interpersonal skills in addition to her public speaking skills. She added, "We meet new people, new personalities, different personalities, sometimes strange personalities... we need to know how to interact with them." In addition to public speaking skills, Nada insisted that she needs to improve her meeting skills because meetings involve new topics and discussion skills, and that requires more confidence and knowledge. Rema thinks improving her public speaking skills is very important because this is a must for EFL learners, as they speak languages other than their native tongues. She feels stressed when talking in front of others in English, particularly if the audience includes the dean and the vice dean. Hana has the same beliefs and claims, "If you want me to speak Arabic, it is okay. I can speak now, but in English I need to prepare myself."

The participants strongly agreed that participating in extracurricular activities helps them to improve their communication skills as EFL learners. Rana claimed that she meets new people of various ages through these activities, and this helps her to improve her communication skills. Mona strongly agreed that those who want to improve their English in addition to their communication skills can find ample opportunities in extracurricular activities. Based on her observation, some students become more fluent speakers and flexible communicators after joining activities. They can also learn from the teachers who supervise the activities and benefit from their experiences with teaching English and communicating with others. During the breast cancer activity, for example, Nouf claimed that the participants searched the Internet to find information about the topic in English and presented it in English. They practiced new medical 
words, which increased their self-esteem during communication. During the coworker activity, the participants met the workers at the college and asked them to translate some thanking statements to the coworkers' language. They pretended that this was an assignment for a translation course. The nice translated statements were presented as a surprise on the day of the activity, which had a very positive effect on the coworkers, who showed amazing reactions. Such activities "don't only improve English. We improve our ability to communicate with others and interact with others," as Nouf claimed. Nada agreed and added that discussions with others during the activities and after the activities are very helpful. Lena stated that she improves her communication skills by communicating with different people through Twitter and explaining the activities to them. She said, "I talk with many people. I know some people. I started to know how to communicate with people without seeing them." Yara claimed that participating in extracurricular activities enables her to meet with graduate students and learn from their experiences. Also, participating in these types of activities improves students' problem-solving skills because the students learn how to be ready to solve any type of anticipated and unanticipated problems. The participants agreed that "plan B" is one of the interesting things they learn from participating in extracurricular activities.

\section{Classroom Activities versus Extracurricular Activities}

The participants agreed that a great difference exists between classroom activities and extracurricular activities in improving their communication skills and lowering levels of CA. They argued that classroom activities can help them to interact and communicate in English; however, such interaction is usually restricted to the classroom environment with students who are taking the same course at the same level and in the same section with the same teacher. Extracurricular activities, on the other hand, involve meeting different teachers and students from various levels at the same college or at different colleges or universities with different majors and interests. They also argued that textbooks rarely provide suggestions for real-life communication and interaction using English and that such options are found through extracurricular activities. Additionally, classroom activities mostly revolve around academic topics per the requirements of the course, whereas extracurricular activities include a variety of voluntary topics. Lena pointed out that some teachers are more creative than others in creating course-related activities that can be performed outside of the classroom. However, such activities are graded at the end, which is one of the major differences between classroom activities and extracurricular activities. Classroom activities are mainly performed to fulfill the requirements of the course, and the course teacher evaluates them whereas extracurricular activities are free and are usually appreciated, as the participants personally choose them to express their talents and creativity. Mona said, "We are not comfortable in the class because the teacher will give us grades, but in the activity unit we help each other." Rana added, "It is a different atmosphere. It is something I like. I do it because I like it." Hana described the reason for participating in extracurricular activities as "inner desire. You do it. You chose it. It is free." Nada stated that students in extracurricular activities practice various talents in different fields. Thus, students can improve their communication skills through extracurricular activities more than they can through classroom activities.

Moreover, the students claimed that the roles they assume in extracurricular activities are different from the ones they can perform in class. Nouf said that classroom activities usually take the form of presentations, where the role of the presenter is mainly to talk, and other students 
listen and ask questions. However, in extracurricular activities, students discuss and interact with others, and they assume many roles. For example, the participants assume the roles of planners, organizers, leaders, and supervisors. The participants also stated that they can perform any role that can help to make the activity successful. They also change roles as needed depending on the nature of the activities. This is not always possible with classroom activities, however, as roles are usually determined from the beginning. Rana and Nouf strongly stated that they never think of which role to choose and that they focus on the result of the activity and how to make it more wonderful. Lena also said, "It is not a big deal for me. Usually I like to plan and supervise, but I can do anything." According to all of the participants, participating in extracurricular activities enhances their leadership skills and raises their self-confidence. The variety of roles that they assume in such activities, and the flexibility they have in changing roles have a positive effect on their personalities and help them to improve their communication skills.

\section{Willingness to Participate in the Future}

Due to the great benefits that participating in extracurricular activities offers in terms of improving communication skills and lowering levels of $\mathrm{CA}$, all participants showed a great willingness to participate in these activities in the future. Rana feels that her activity team members are her family and believes that voluntary work and extracurricular activities lead to happiness and a good mood. Nouf added that she likes to improve her leadership and communication skills and help others through extracurricular activities, stating, "I find myself there." Yara added, "I notice how it helps me and how it improves all aspects in my personality." She further claimed that she learns how to communicate with others during the activities more effectively than she does in the courses. Rema argued that it is part of her personality to help others, and she said that one of the goals of extracurricular activities is to provide help, show gratitude, and express feeling and thanks. For example, in the coworker activity, they expressed their gratitude to coworkers and thanked them for their essential roles in the college, and this is what Rema truly loves. She added, "It is something fun." Mona stated that she can speak English and practice real-life situations more through activities. She also believes that "As a volunteer in the activity unit, I have always to be kind and smile." Hana loves the extracurricular activities from her childhood. She cannot imagine her life without activities and cannot go the entire day without taking breaks that refresh her mood. Extracurricular activities are the best choice for her because as she claimed, "It is part of my life." Lena added, "I love the activities because of the established relationships between me and my talents and my personal life and others." Such benefits help with creating social people who love to communicate with others and improve their communication. Rema and Lena further pointed out that participation in extracurricular activities prepares them for future jobs as they are more confident, ready to express themselves and to show their talents and creativity, and convince others. The participants argued that extracurricular activities can be improved to be more effective in the future by inviting people from outside of the university particularly native speakers to benefit from their experiences. Some participants argued that extracurricular activities can be developed if new students particularly those from younger levels join activities and share more activity ideas and talents. This will, in turn, lead to improving communication skills, which the participants claimed. 


\section{Discussion}

The aim of this study was to examine the relationship between involvement in extracurricular activities and students' CA level and explore the students' perspectives regarding the effect of extracurricular activities on their communication skills. The quantitative analysis of data collected in this study showed a positive relationship between participating in extracurricular activities and levels of CA. To clarify, the results showed that the group that participated in more than five activities included no participants with high CA level (0\%) and that $78 \%$ of participants with low CA level were part of the same group that participated in more than five activities. The results also showed that only $7.5 \%$ of all participants had high levels of $\mathrm{CA}$, which is a low percentage when compared with the other two levels; moderate $(70 \%)$ and low $(22.5 \%)$. Additionally, there was a significant difference between the $1-2$ activities group and the more than five activities group, whereas no significant differences were found between the 1 - 2 activities group and the 3 - 4 activities group and between the 3 - 4 activities group and the more than five activities group. This clearly indicates a difference between students who participate more in the activities and those who participate less and that more participation in extracurricular activities helps students overcome high levels of CA. This can be attributed to the fact that more participation in extracurricular activities enables participants to practice real-life communication, and improve their skills, which in turn reduces CA. Such findings are consistent with those of Eccles et al. (2003), who found that participation in extracurricular activities helps in practicing social and intellectual skills needed in a variety of settings and developing a greater sense of involvement in the community.

According to the data analysis, the percentage of participants with a moderate CA level (70\%) was the highest among the three levels. This is in line with McCroskey's (1984) findings that many students experience some CA levels, particularly during public communication. This high percentage of moderate CA levels can be considered a good indicator of the positive effect of participation in extracurricular activities and can be justified by the fact that participants are still undergraduates in the process of learning and improving their communication skills. This is consistent with the results obtained through the qualitative analysis of the semi-structured interviews in this study. The interviewed participants stated that they all experience some level of CA, although they have a great desire to participate in various activities. They also claimed that they still need to improve various communication skills which is supported by the analysis of participants' responses to the questionnaire, showing that $100 \%$ of the participants agree on this need. The study also showed that more than half of the participants (51\%) agree that they need to improve public speaking skills, which is in line with findings provided by LeFebvre et al. (2018) indicating that undergraduates experience both internal and external fear associated with public speaking. The participants in this study also stated that meeting new people and communicating with different personalities make it necessary to improve communication skills, particularly as EFL learners who speak a language other than their native language, which constitutes an additional burden. This is consistent with research findings described in other studies (Mahdi, 2015; Schlenker\& Leary, 1982).

The study also showed that all participants (100\%) agree that participating in extracurricular activities helps them improve various communication skills. This has also been proven by other researchers, such as Jamal (2012), who found that participants in extracurricular activities gained many communication and interpersonal skills. The participants in this study also 
strongly stated that through interacting (either face-to-face or online) with people of different ages and personalities and contacting teachers, they learned many social behaviors and became more successful communicators. Furthermore, researching the topic of the activity expands their knowledge and adds to their self-confidence while communicating in English with others. Developing problem-solving skills is one of the beneficial things they learned from participating in extracurricular activities, which definitely results in great improvements in communication skills. All participants (100\%) stated that they would like to participate in extracurricular activities in the future because of the great benefits they gained from these activities in improving their communication skills and reducing CA. This finding supports those of Eccles et al. (2003), who claimed that regular extracurricular activities help adolescents create good social networks that aid them in both the present and the future.

The participants in the current study believe that more involvement in extracurricular activities prepares them for future jobs after graduation which is consistent with Tchibozo's (2007) results. The participants suggested that extracurricular activities be developed to facilitate communication skill improvement by inviting native speakers from outside the university to exchange experiences and by motivating new students to join the unit. Such findings clearly indicate that the students have positive attitudes toward participating in extracurricular activities and that involvement in such activities helps them improve their communication skills and overcome CA, which leads to development of language proficiency. Such findings are in line with those of Mahoney et al. (2003), who found a positive correlation between regular participation in extracurricular activities and long-term educational success.

This study also revealed that $93 \%$ of the participants try to improve their communication skills by using English outside the college. This reflects the students' willingness to improve their communication skills through a variety of extracurricular activities beyond their homework. Additionally, results showed that $37 \%$ of the participants like to perform leadership roles, which means that those students have high self-confidence and good interpersonal skills and believe in their capability to lead a team. This is in line with findings provided by Lau, Hsu, Acosta, and Hsu (2014) that students who are core members of extracurricular activities positively evaluate their communication and leadership skills. The participants also expressed their desire to perform a variety of roles in the activities, which indicates that they are enthusiastic and highly motivated to work on different tasks and express themselves through holding various responsibilities via extracurricular activities. This also indicates that they have good communication skills that enable them to complete a variety of tasks. All participants agreed that they improved their communication skills through performing these roles in the extracurricular activities. The findings of the current study also showed that $68 \%$ of the participants are ready to participate in all kinds of activities and that the purpose of the activity is more important than its type. They aim at providing assistance and making people happy. The remaining 32\% of the participants expressed their desire to raise awareness of important social issues. All participants strongly agreed that such activities helped them improve their communication skills and overcome some levels of fear and anxiety in communication. This is in line with Makarova and Reva's (2017) results. The participants also agreed that communication skills can be improved through extracurricular activities more than through classroom activities. This is because classroom activities are related to course topics to be graded by the teacher. This is in line with Mustapha et al.'s (2010) finding that fear of negative evaluation is the source of classroom anxiety for most 
students. The roles that students perform in classroom activities are usually limited and do not contribute to communication skill improvement. The participants also claimed that textbooks rarely provide opportunities for interaction and communication, as opposed to the many options in extracurricular activities. This supports Bragg's (2017) finding that teaching materials do not help students improve their communication skills.

This study also revealed that participants are open to meeting others and communicating in English. They believe in their capability to persuade others and understand personalities in a way that facilitates communication. However, they all claimed that they still experience some levels of CA under certain circumstances. They stated that sources of CA can be the presence of a new comer, stress due to inaccurate pronunciation, misunderstanding, or face-to-face communication. This justifies the higher percentage of moderate levels of CA described earlier. The analysis of data collected in this study through different research instruments led to the following theory: More involvement in extracurricular activities helps participants overcome higher levels of CA and improve their communication skills, and participants have very positive perspectives regarding the activities and their effectiveness in improving communication skills and reducing communication fears and anxiety.

\section{Conclusion}

This study attempted to examine the relationship between participation in extracurricular activities and levels of Communication Apprehension among EFL students and explore the students' perspectives of how extracurricular activities affect their communication skills. The data analysis showed a positive relationship between more involvement in extracurricular activities and levels of CA. The results showed that the group that participated in more than five activities included no participants with high CA $(0 \%)$ and that $78 \%$ of participants with low CA were part of the same group that participated in more than five activities. The results also showed that only $7.5 \%$ of all participants had high levels of CA, which is a low percentage when compared with the other two levels; moderate (70\%) and low (22.5\%). Additionally, there was a significant difference between the 1 - 2 activities group and the more than five activities group, and there were no significant differences between the 1 - 2 activities group and the 3 - 4 activities group and between the 3 - 4 activities group and the more than five activities group.

The study also showed that the participants have positive perspectives regarding the effect of extracurricular activities on their communication skills. They believe that participation in extracurricular activities helps them improve their communication skills and reduce levels of CA, particularly as EFL learners. They all showed great willingness to participate in extracurricular activities in the future, as they are very helpful in improving their communication skills and preparing them for future jobs. The participants are ready to perform a variety of roles in different activities and stated that they improve their communication skills through performing different roles. They also agreed that such communication skill improvement is achieved through participation in extracurricular activities more than through classroom activities.

\section{Limitations of the study}

1- The findings of the study cannot be generalized before conducting similar studies with larger samples. 
2- Only female students at the College of Languages and Translation at Imam Mohammed bin Saud Islamic University in Riyadh were involved in the study.

3- The study was focused on the relationship between participation in extracurricular and levels of CA.

4- The study only explored the effect of extracurricular activities on communication skills from students' perspectives.

$5-$

\title{
Recommendations
}

Based on the findings of the present study, which show the importance of extracurricular activities in overcoming CA and improving communication skills, it is highly recommended to encourage all EFL students, particularly those with high CA, to participate in such activities. It is also recommended that teachers who supervise extracurricular activities give students workshops on how to choose activities and roles according to their interests and needs. Students who participate in extracurricular activities are also recommended to give workshops to share their experiences in these activities and help their peers. Teachers should carefully design the activities in a way that makes them more effective in improving EFL students' communicative abilities and reducing CA. EFL teaching material developers are highly encouraged to consider including a variety of extracurricular activities in teaching curricula. It is also recommended to include extracurricular activities in course requirements to ensure students' involvement in such activities.

For future research in the field, the following are suggested:

- Comparing female students to male students in terms of CA levels, participation in extracurricular activities, and their perspectives.

- Investigating the perspectives of students with high CA regarding participation in extracurricular activities.

- Exploring why some students avoid participating in extracurricular activities.

- Examining levels of CA among students who do not participate in extracurricular activities.

- Examining the effect of extracurricular activities on students with high CA levels.

- Including larger samples to generalize the findings of this study.

- Exploring EFL teachers' perspectives regarding the effect of participating in extracurricular activities on students' communication skills.

\begin{abstract}
About the author:
Dr. Lubna Alnaeem, assistant professor at the Department of English Language and Literature, College of Languages and Translation, Imam Mohammad Ibn Saud University (IMSIU), Riyadh, Saudi Arabia. The author is interested in language teaching and learning, curriculum development, and teacher cognitions. https://orcid.org/0000-0002-1714-7768
\end{abstract}

\section{References}

Amogne, D., \&Yigzaw, A. (2013). Oral communication apprehension, competence and performance among maritime engineering trainees. Journal of Media and Communication Studies, 5(1), 5-11.

Bodie, G. D. (2010). A racing heart, rattling knees, and ruminative thoughts: Defining, explaining, and treating public speaking anxiety. Communication Education, 59(1), 70-

105.https://doi.org/10.1080/03634520903443849 
Borg, S. (2006). Teacher cognition and language education. Research and practice. London. Continuum. Bragg, J. (2017). Communication apprehension among community college students: A phenomenology, (Unpublished Doctoral dissertation). East Tennessee State University. Available at https://dc.etsu.edu/cgi/viewcontent.cgi?article=4611\&context=etd

Byrne, M., Flood, B., \& Shanahan, D. (2012). A qualitative exploration of oral communication apprehension. Accounting Education, 21(6), 556581.https://doi.org/10.1080/09639284.2012.725636

Chen, J.,\& Wang, Y. (2013). A study of cooperative learning in higher college English teaching. Theory and Practice in Language Studies, 3(7), 1258-1263. doi:10.4304/tpls.3.7.1258-1263

Dörnyei, Z. (2007). Research methods in applied linguistics: Quantitative, qualitative and mixed methodologies. Oxford: Oxford University Press.

Eccles, J. S., Barber, B. L., Stone, M., \& Hunt, J. (2003). Extracurricular activities and adolescent development. Journal of Social Issues,59(4), 865-889.https://doi.org/10.1046/j.00224537.2003.00095.X

Francis, T. A., \& Miller, M. T. (2008). Communication apprehension: Levels of first-generation college students at 2-year institutions. Community College Journal of Research \& Practice, 32(1), 38 55.https://doi.org/10.1080/10668920701746688

Freimuth, V. S. (1976). The effects of communication apprehension on communication effectiveness. Human Communication Research,2(3), 289-298.https://doi.org/10.1111/j.14682958.1976.tb00488.x

Jamal, A. A. (2012). Developing interpersonal skills and professional behaviors through extracurricular activities participation: A perception of King Abdulaziz University medical students. Journal of King Abdulaziz University: Medical Sciences, 98(373), 1-43. DOI: 10.4197/Med. 19-4.1

Lau, H. H., Hsu, H. Y., Acosta, S., \& Hsu, T. L. (2014). Impact of participation in extra-curricular activities during college on graduate employability: An empirical study of graduates of Taiwanese $\quad$ business $\quad$ schools. Educational $\quad$ Studies, 40(1), 2647.https://doi.org/10.1080/03055698.2013.830244

LeFebvre, L., LeFebvre, L. E., \& Allen, M. (2018). Training the butterflies to fly information: Cataloguing student fears about public speaking. Communication Education, 67(3), 348362.https://doi.org/10.1080/03634523.2018.1468915

Mahdi, D. (2015). Relationship between oral communication apprehension and communication competence among EFL Students. King Khalid University Journal for Humanities, 24(3), 289306.

Mahoney, J., Beverley, D., \& Thomas, W. (2003) Promoting interpersonal competence and educational success through extracurricular activity participation. Journal of Educational Psychology, 95(2), 409-418.https://doi.org/10.1037/0022-0663.95.2.409

Makarova, V., \& Reva, A. (2017). Perceived impact of extra-curricular activities on foreign language learning in Canadian and Russian university contexts. Apples: Journal of Applied Language Studies, 11(1), 43-65.Retrieved from http://apples.jyu.fi/article/abstract/486

Malinovska, L. (2011). Promotion of engineering student competences in extra-curricular activities. In Engineering for rural development - Proceedings of the 10th International Scientific Conference (pp. 508-513). Jelgava.

McCroskey, J. C. (1982). Oral communication apprehension: A reconceptualization. In M. Burgoon (Ed.),Communication yearbook (Vol. 6, pp. 136-170). Beverly Hills, CA: Sage.

McCroskey, J.C. (1984). The communication apprehension perspective. In J.A. Daly \& J. C. McCroskey (Eds.) Avoiding communication: Shyness, reticence and communication apprehension (pp. 1338). Beverly Hills, CA: Sage.

McCroskey, J. C. (2009). Communication apprehension: What have we learned in the last four decades. Human Communication, 12(2), 157-171. 
McCroskey, J. C., Beatty, M. J., Kearney, P., \& Plax, T. G. (1985). The content validity of the PRCA- 24 as a measure of communication apprehension across communication contexts. Communication Quarterly, 33(3), 165-173.

McCroskey, J. C., Booth-Butterfield, S., \& Payne, S. K. (1989). The impact of communication apprehension on college student retention and success. Communication Quarterly, 37(2), 100107.

McCroskey, L. L., Teven, J. J., Minielli, M. C., \& Richmond McCroskey, V. P. (2014). James C. McCroskey's instructional communication legacy: Collaborations, mentorships, teachers, and students. Communication Education, 283307.https://doi.org/10.1080/03634523.2014.911929

Montelongo, R. (2002). Student participation in college student organizations: A review of literature. Journal of the Student Personnel Association at Indiana University, 50-63.Retrieved from https://scholarworks.iu.edu/journals/index.php/jiuspa/article/view/4617

Mustapha, W. Z. W., Ismail, N., Singh, D. S. R., \& Elias, S. (2010). ESL students' communication apprehension and their choice of communicative activities. ASEAN Journal of Teaching and Learning in Higher Education, 2(1), 22-29.

Nghia, T. L. H. (2017). Developing Generic Skills for Students via Extra-Curricular Activities in

Vietnamese Universities: Practices and Influential Factors. Journal of Teaching and Learning for

Graduate Employability, 8(1), 22-39.

Olibie, E. I., \& Ifeoma, M. (2015). Curriculum enrichment for $21^{\text {st }}$ century skills: A case for arts based extracurricular activities for students. International Journal of Recent Scientific Research, 6(1), $4850-4856$.

Payton, K.E., \& Scott, J.A. (2013). Communication apprehension among homeschooled college freshmen. Focus on Colleges, Universities, and Schools, 7(1), 1-10.

de Prada Creo, E., Mareque, M., \& Portela-Pino, I. (2020). The acquisition of teamwork skills in university students through extra-curricular activities. Education +Training. https://doi.org/10.1108/ET07-2020-018

Rashidi, N., Yamini, M., \&Shafiei, E. (2012). Oral communication apprehension and affective factors: Self-esteem and introversion/extroversion. Journal of English Language Teaching and Learning, $3(7), 145-174$.

Rubin, R. B., Graham, E. E., \& Mignerey, J. T. (1990). A longitudinal study of college students' communication competence. Communication Education, 39(1), 114.https://doi.org/10.1080/03634529009378783

Saibovich, S. A. (2019). Extracurricular activities: Success and development of communication skills with the role of parents, public and home work. International Journal of Management Science and Business Administration, 6 (1), 21-26.

Schlenker, B. R., \& Leary, M. R. (1982). Social anxiety and self-presentation: A conceptual model. Psychological Bulletin, 92(3),641-669.doi: 10.1037/0033-2909.92.3.641.

Simoncini, K., \&Caltabiono, N. (2012). Young school-aged children's behaviour and their participation in extra-curricular activities. Australasian Journal of Early Childhood, 37(3), 35-42.

Tchibozo, G. (2007). Extracurricular activity and the transition from higher education to work: A survey of graduates in the United Kingdom. Higher Education Quarterly,61(1), 3756.https://doi.org/10.1111/j.1468-2273.2006.00337.x 


\section{Appendices \\ Appendix A \\ PRCA-24}

Dear extracurricular activity unit volunteers,

Directions: This instrument is composed of 24 statements concerning your feelings about communication with other people. In the space provided, please indicate the degree to which each statement applies to you by marking whether you (1) Strongly Agree, (2) Agree, (3) Are Undecided, (4) Disagree, or (5) Strongly Disagree with each statement. There are no right or wrong answers. Many of the statements are similar to other statements. Do not be concerned about this. Work quickly, and just record your first impression.

Name (you can write your real name or any name you like):

\begin{tabular}{|c|c|}
\hline Statement & Response \\
\hline 1. I dislike participating in group discussions. & $\begin{array}{ll}\text { (1) Strongly (2) Agree } & \text { (3) Undecided } \\
\text { (4) Disagree } & \text { (5) Strongly Disagree }\end{array}$ \\
\hline $\begin{array}{l}\text { 2. Generally, I am comfortable while participating in } \\
\text { group discussions. }\end{array}$ & $\begin{array}{ll}\text { (1) Strongly Agree } & \text { (2) Agree (3) Undecided } \\
\text { (4) Disagree } & \text { (5) Strongly Disagree } \\
\end{array}$ \\
\hline $\begin{array}{l}\text { 3. I am tense and nervous while participating in group } \\
\text { discussions. }\end{array}$ & $\begin{array}{l}\text { (2) Agree (3) Undecided } \\
\text { (5) Strongly Disagree }\end{array}$ \\
\hline 4. I like to get involved in group discussions. & $\begin{array}{l}\text { (2) Agree (3) Undecided } \\
\text { (5) Strongly Disagree }\end{array}$ \\
\hline $\begin{array}{l}\text { 5. Engaging in a group discussion with new people } \\
\text { makes me tense and nervous. }\end{array}$ & $\begin{array}{l}\text { (2) Agree (3) Undecided } \\
\text { (5) Strongly Disagree }\end{array}$ \\
\hline $\begin{array}{l}\text { 6. I am calm and relaxed while participating in group } \\
\text { discussions. }\end{array}$ & $\begin{array}{l}\text { (2) Agree (3) Undecided } \\
\text { (5) Strongly Disagree }\end{array}$ \\
\hline $\begin{array}{l}\text { 7. Generally, I am nervous when I have to participate } \\
\text { in a meeting. }\end{array}$ & $\begin{array}{l}\text { (2) Agree (3) Undecided } \\
\text { (5) Strongly Disagree }\end{array}$ \\
\hline $\begin{array}{l}\text { 8. Usually, I am calm and relaxed while participating in } \\
\text { meetings. }\end{array}$ & $\begin{array}{l}\text { (2) Agree (3) Undecided } \\
\text { (5) Strongly Disagree }\end{array}$ \\
\hline $\begin{array}{l}\text { 9. I am very calm and relaxed when I am called upon to } \\
\text { express an opinion at a meeting. }\end{array}$ & $\begin{array}{l}\text { (2) Agree (3) Undecided } \\
\text { (5) Strongly Disagree }\end{array}$ \\
\hline 10. I am afraid to express myself at meetings. & $\begin{array}{l}\text { (2) Agree (3) Undecided } \\
\text { (5) Strongly Disagree }\end{array}$ \\
\hline $\begin{array}{l}\text { 11. Communicating at meetings usually makes me } \\
\text { uncomfortable. }\end{array}$ & $\begin{array}{l}\text { (2) Agree (3) Undecided } \\
\text { (5) Strongly Disagree }\end{array}$ \\
\hline $\begin{array}{l}\text { 12. I am very relaxed when answering questions at a } \\
\text { meeting. }\end{array}$ & $\begin{array}{l}\text { (2) Agree (3) Undecided } \\
\text { (5) Strongly Disagree }\end{array}$ \\
\hline $\begin{array}{l}\text { 13. While participating in a conversation with a new } \\
\text { acquaintance, I feel very nervous. }\end{array}$ & $\begin{array}{l}\text { (2) Agree (3) Undecided } \\
\text { (5) Strongly Disagree }\end{array}$ \\
\hline 14. I have no fear of speaking up in conversations. & $\begin{array}{l}\text { (2) Agree (3) Undecided } \\
\text { (5) Strongly Disagree }\end{array}$ \\
\hline $\begin{array}{l}\text { 15. Ordinarily, I am very tense and nervous in } \\
\text { conversations. }\end{array}$ & $\begin{array}{l}\text { (2) Agree (3) Undecided } \\
\text { (5) Strongly Disagree }\end{array}$ \\
\hline $\begin{array}{l}\text { 16. Ordinarily, I am very calm and relaxed in } \\
\text { conversations. }\end{array}$ & $\begin{array}{l}\text { (2) Agree (3) Undecided } \\
\text { (5) Strongly Disagree }\end{array}$ \\
\hline $\begin{array}{l}\text { 17. While conversing with a new acquaintance, I feel } \\
\text { very relaxed. }\end{array}$ & $\begin{array}{l}\text { (2) Agree (3) Undecided } \\
\text { (5) Strongly Disagree }\end{array}$ \\
\hline 18. I'm afraid to speak up in conversations. & $\begin{array}{l}\text { (2) Agree (3) Undecided } \\
\text { (5) Strongly Disagree }\end{array}$ \\
\hline 19. I have no fear of giving a speech. & $\begin{array}{l}\text { (2) Agree (3) Undecided } \\
\text { (5) Strongly Disagree }\end{array}$ \\
\hline
\end{tabular}


Arab World English Journal (AWEJ) Volume 12. Number 2. June 2021

Involvement in Extracurricular Activities and Overcoming High Levels

Alnaeem

\begin{tabular}{|l|ll|}
\hline $\begin{array}{l}\text { 20. Certain parts of my body feel very tense and rigid } \\
\text { while giving a speech. }\end{array}$ & $\begin{array}{l}\text { (1) Strongly Agree } \\
\text { (4) Disagree }\end{array}$ & $\begin{array}{l}\text { (2) Agree (3) Undecided } \\
\text { (5) Strongly Disagree }\end{array}$ \\
\hline 21. I feel relaxed while giving a speech. & $\begin{array}{l}\text { (1) Strongly Agree } \\
\text { (4) Disagree }\end{array}$ & $\begin{array}{l}\text { (2) Agree (3) Undecided } \\
\text { (5) Strongly Disagree }\end{array}$ \\
\hline $\begin{array}{l}\text { 22. My thoughts become confused and jumbled when I } \\
\text { am giving a speech. }\end{array}$ & $\begin{array}{l}\text { (1) Strongly Agree } \\
\text { (4) Disagree }\end{array}$ & $\begin{array}{l}\text { (2) Agree (3) Undecided } \\
\text { (5) Strongly Disagree }\end{array}$ \\
\hline $\begin{array}{l}\text { 23. I face the prospect of giving a speech with } \\
\text { confidence. }\end{array}$ & $\begin{array}{l}\text { (1) Strongly Agree } \\
\text { (4) Disagree }\end{array}$ & $\begin{array}{l}\text { (2) Agree (3) Undecided } \\
\text { (5) Strongly Disagree }\end{array}$ \\
\hline $\begin{array}{l}\text { 24. While giving a speech, I get so nervous I forget } \\
\text { facts I really know. }\end{array}$ & $\begin{array}{l}\text { (1) Strongly Agree } \\
\text { (4) Disagree }\end{array}$ & $\begin{array}{l}\text { (2) Agree (3) Undecided } \\
\text { (5) Strongly Disagree }\end{array}$ \\
\hline
\end{tabular}

Thank you so much for participating.

\section{Appendix B}

Questionnaire

Dear extracurricular activity unit volunteers,

I would like to thank you so much for agreeing to participate. Please read the statements and give accurate answers.

All information will be kept confidential and will be used for the purpose of the study only.

1-Name: (please write the name that you used in the PRCA-24)

2-Your level at the college:

3-Do you try to improve your communication skills using English outside the classroom?

Yes No

4-How many times have you participated extracurricular in activities?

1-2 3-4 more than 5

5-What kinds of extracurricular activities are you interested in?

6- Do you want to improve your communication skills?

Yes No

7- What communication skills would you like to improve?

- Group discussion skills

- Meeting skills

- Interpersonal skills

- $\quad$ Public speaking skills

8-Do you think that extracurricular activities can help you improve your communication skills?

Yes No

9-What is the role that you like to perform in extracurricular activities?

10- Do you think that performing these roles can help you improve your communication skills?

Yes No

11-Would you like to participate in extracurricular activities in the future?

Yes No

12-Can you suggest any extracurricular activities to be held at the college?

Thank you so much for participating.

\section{Appendix C}

\section{Interview Guiding Questions}

1- Can you identify some points of strength and weakness in your personality while communicating with others in English?

2- Why did you join the extracurricular activity unit?

3- What kinds of communication skills would you like to improve? 
4- Do you think that participating in extracurricular activities helps you as an EFL learner improve your communication skills? (If yes, how? If no, why?)

5- In your opinion, how do extracurricular activities differ from classroom activities concerning communication skills?

6- What advantages can you list from participating in extracurricular activities?

7- Are there any disadvantages of participating in extracurricular activities? (If yes, what are they?)

8- How do you prepare yourself for extracurricular activities?

9- What kinds of extracurricular activities are you interested in? Why?

10- Which activity do you enjoy the most? Why?

11- What kinds of extracurricular activities do you not like to participate in? Why?

12- How can we make extracurricular activities more effective?

13- What is the role that you like to perform in extracurricular activities? Why?

14- How do you improve your communication skills outside the college?

15- Would you like to participate in any extracurricular activities in the future? Why? Give me a final remark, please. 